\title{
Comparison of the treatment of herpes genitalis in men with proflavine photoinactivation, idoxuridine ointment, and normal saline
}

\author{
P. K. TAYLOR AND N. R. DOHERTY \\ From the Whitechapel Clinic and the Department of Virology, The London Hospital
}

The principle of photodynamic inactivation was first described by Raab (1900) in experiments with paramecia. In low concentrations of methylene blue, paramecia died rapidly on exposure to daylight while remaining alive if kept in the dark. Perdrau and Todd (1933) and Shortt and Brooks (1934) showed that viruses were photosensitized by methylene blue. Hiatt, Kaufmann, Helprin, and Baron (1960) extended the work of Yamamoto (1958), on the photodynamic inactivation of bacteriophage, to certain animal viruses including herpes simplex virus (HSV). Wallis and Melnick (1964) described how certain heterotricyclic dyes could be bound irreversibly to herpes virus in vitro, subsequent brief exposure to fluorescent light causing inactivation of the virus. The most effective dyes were found to be neutral red, proflavine, and toluidine blue. The following year the same authors (Wallis and Melnick, 1966) reviewed this photodynamic inactivation of viruses and suggested that treatment of herpetic lesions with heterotricyclic dyes and light might be clinically beneficial.

Moore, Wallis, Melnick, and Kuns (1972) had good results from treatment using photodynamic inactivation in experimentally induced herpes keratitis in rabbits. Felber, Smith, Knox, Wallis and Melnick (1971) reported that 87 per cent. of sixty patients with recurrent labial or genital HSV said that the results of this method of treatment were better than those of anything they had tried before. In a further study the same authors (Felber, Smith, Knox, Wallis, and Melnick, 1973) reported that eighteen of twenty patients with labial or genital herpes had symptomatic improvement, half showing an improvement in healing time. After follow up for between 18 and 30 months, 85 per cent. of patients had a decrease in recurrence rate (only 11 per cent. of recurrences were at the same site). A control group treated with phenol sulphonphthalein, which has no known photoreactive or virucidal activity, had subjective improvement in 50 per cent. of cases. This 'placebo' effect has previously been noted in studies of inReceived for publication July 31,1974 fection by HSV (Wallis, Melnick, and Kaufman, 1972). Although the treatment was effective against both type 1 and type $2 \mathrm{HSV}$, it was apparently greater against type 2 .

Hood, quoted by Wallis and others (1972), had comparable successes to those of Felber and others (1973) in herpes genitalis of the penis and vulva. Lefebvre and McNellis (1973) had similar results in eleven cases and Schneider and Geary (1971) reported comparable success in herpes simplex vulvitis. Friedrich (1973) reported marked relief of symptoms in twenty-four of thirty patients with herpes vulvitis within 36 hours and healing usually within 7 days. It was suggested in the British Medical fournal (1974) that an added advantage of photodynamic inactivation might be that the dye minimized secondary bacterial infection.

Of other treatments for herpetic infection, systemic cytarabine has been used in herpetic vulvitis with good results by Juel-Jensen (1973). The most widely used remedy is probably 5-iodo-2' deoxyuridine (IDU). Hutfield (1964) reported favourably on the use of this agent. Schofield (1964) reported that the healing time in 22 patients with previous herpetic infection was halved. Prusoff (1967) recommended IDU for the treatment of herpetic infection. However $\mathrm{Ng}$, Reagan, and Yen (1970) reported that the duration of the disease and the incidence of recurrent lesions were unaffected by local IDU 3-hourly in twenty-two patients with herpes simplex vulvitis. Wallis and others (1972) also reported unsatisfactory results in herpes genitalis using IDU ointment, and Kaufman, Mantola, and Dohlman (1962) reported that the good results of aqueous IDU in herpetic keratitis had not been duplicated in genital herpetic infection. Juel-Jensen (1973) stated that IDU in watery solution or ointment does not penetrate the skin and is therefore inactive in skin lesions. To be effective it must be dissolved in dimethyl sulphoxide (DMSO). IDU is less effective against type 2 than type 1 HSV (Fournal of the American Medical Association, 1971; Person, Sheridan, and Hermann, 1972; Juel-Jensen 1973). 
In view of the reported success of photodynamic inactivation in the treatment of herpetic infection, it was decided to study the results of photoinactivation, using proflavine as the dye, in men suffering from herpes genitalis. Results were compared with those in a group treated with IDU and with those in a control group using saline bathing only. Because most of the previous studies relied to a large extent upon subjective observations, it was decided to measure the areas of the lesions as an objective guide to the progress of treatment.

\section{Patients and methods}

All male patients attending the Whitechapel Clinic with typical herpetic lesions of the genitalia who were considered likely to attend for follow-up were allocated to one of three treatment groups in turn:

(1) Proflavine photoinactivation

(2) IDU

(3) Normal saline

Syphilis was excluded by dark-field examination for treponemes and in some cases by fluorescent antibody (FA) staining for treponemes. A Reiter protein complement-fixation test (RPCFT), automated reagin test (ART), and an absorbed fluorescent treponemal antibody (FTA-ABS) test were carried out initially in all cases and repeated later if possible. When the dark-field examination was reported negative for $T$. pallidum, material for culture for HSV was taken from the lesion and a specimen of blood was taken for a titred complement-fixation test for antibody to HSV. The lesions were then measured (see below), after which treatment was started. If vesicles were present these were ruptured with a sterile needle before treatment.

Group 1 Proflavine photoinactivation

The lesions were flooded with an excess of 0.1 per cent. proflavine solution. This was repeated after $1 \mathrm{~min}$. The affected area was then exposed to light from a 15 watt fluorescent tube for $15 \mathrm{~min}$. at a distance of $6 \mathrm{in}$. This treatment was repeated after 24 and $48 \mathrm{hrs}$.

\section{Group 2 IDU}

IDU ointment $(0.5$ per cent.) was applied to the lesions and the affected area exposed to light as in Group 1. The patient was instructed to apply IDU ointment again the same night and the following morning. This was repeated after 24 and $48 \mathrm{hrs}$. After this the patient was instructed to apply IDU ointment three times daily for a further 5 days.
Group 3 Normal saline

The lesions were bathed in a normal saline solution; they were then exposed to light as in Group 1. This was repeated after 24 and $48 \mathrm{hrs}$ after which the patient was instructed to bathe the lesions in normal saline three times daily for a further 5 days.

Material for culture for HSV was obtained at the first attendance and at each subsequent visit from all patients by means of cotton-wool swabs which were placed in Stuart's transport medium (STM). In the virus laboratory these swabs were extracted in $1.5 \mathrm{ml}$. of maintenance medium (199 tissue culture medium containing 2 per cent. foetal calf serum, $100 \mu \mathrm{g} . / \mathrm{ml}$. gentamicin and $50 \mu \mathrm{g} . / \mathrm{ml}$. mycostatin). The STM was prepared according to Stuart's original formula (Stuart, 1946), with the exception that agarose was used instead of agar. Culture tubes of human embryonic lung cells, maintained on the above medium, were inoculated with $0.2 \mathrm{ml}$. of swab extract, two tubes per specimen, one of which contained specific HSV neutralizing serum. Uninoculated tubes were included as cell controls. These were then incubated at $33^{\circ} \mathrm{C}$. in a roller drum and were examined for cytopathic effect (CPE) daily for 7 days. CPE that was due to HSV was confirmed as such by its absence in the tube containing specific antiserum to HSV.

The area of the lesions was measured at each attendance by the same observer (PKT) by means of an operating microscope fitted with a measuring grid in one eyepiece which enabled an accurate measurement to be obtained in square millimetres. At the initial attendance it was noted if there was a past history of either genital or labial herpes and whether the patient was circumcised. At each attendance symptoms (pain, discomfort, and irritation) were noted on a standard proforma. Also noted were fresh lesions (if any), the sites of lesions, and whether there was any enlargement of inguinal lymph nodes. A further specimen of blood was taken for testing for antibodies to HSV after 3 weeks.

\section{Results}

58 patients were studied (Table I). Of these $39 \mathrm{had}$ positive cultures for HSV. The remainder were excluded from the trial. Three further patients, one from each study group, did not return after their first attendance and were also excluded, leaving 36 patients for assessment.

The healing time of the lesions is shown in Table II. There was no increase in healing rate between 7 and 14 days, although at 21 days almost twice as many had healed in all three groups.

TABLE I Number of patients studied, culture results, and follow up

\begin{tabular}{|c|c|c|c|c|}
\hline Group & No. of patients studied & No. with + ve HSV culture & No. with - ve HSV culture & No. followed \\
\hline (2) IDU & 20 & 14 & 6 & 13 \\
\hline (3) Normal saline & 17 & 8 & 9 & 7 \\
\hline Total & 58 & 39 & 19 & 36 \\
\hline
\end{tabular}


TABLE II Cumulative number of patients with lesions healed at 7, 14, and 21 days after start of treatment

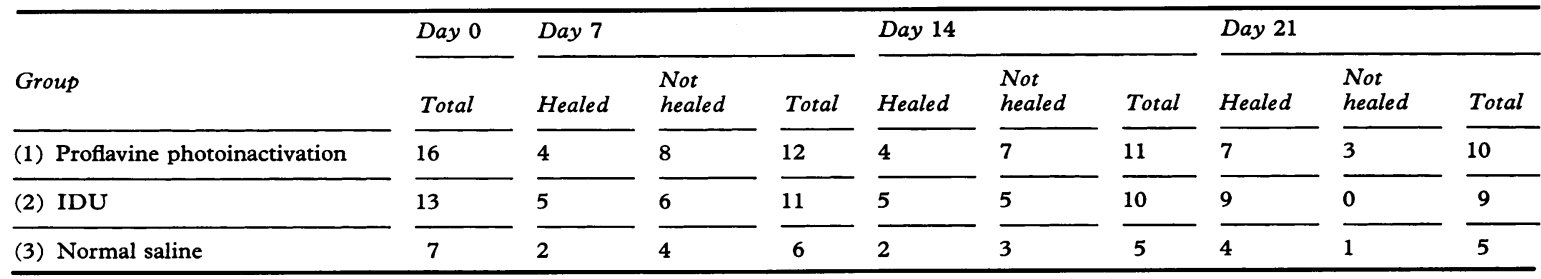

Table III shows the total number of cultures taken from the lesions after the start of treatment and the percentage of positive cultures. The discrepancy between the number of cultures taken and the number of attendances that should have taken place is explained by the default of patients at some attendances.

Table IV shows the area of the lesions at various times after commencement of treatment and also these areas expressed as a percentage of the total area on Day 0 . The initial area varies as some patients defaulted from some follow-up attendances.
Patients were divided into primary or recurrent HSV infection by antibody titre at their first attendance, a titre of 10 or less being classed as primary HSV infection and over 10 as recurrent HSV infection. The healing time of the various groups is shown in Table V. The separation of primary and recurrent $\mathrm{HSV}$ infection by history alone instead of antibody titre showed very similar results. Patients with recurrent $\mathrm{HSV}$ infection showed a quicker overall healing time. The disappearance rate of the

TABLE II I Results of cultures for HSV after treatment

\begin{tabular}{|c|c|c|c|c|c|c|c|c|}
\hline \multirow[b]{2}{*}{ Group } & \multicolumn{4}{|c|}{ Days 1 and 2 after start of treatment } & \multicolumn{4}{|c|}{ Days 7 to 14 after start of treatment } \\
\hline & No. of cultures & $+v e$ & $-v e$ & $\begin{array}{l}\text { Per cent. } \\
+v e\end{array}$ & No. of cultures & $+v e$ & $-v e$ & $\begin{array}{l}\text { Per cent. } \\
+ \text { ve }\end{array}$ \\
\hline (1) Proflavine photoinactivation & 29 & 19 & 10 & 65 & 12 & 6 & 6 & 50 \\
\hline (2) IDU & 22 & 9 & 13 & 41 & 7 & 3 & 4 & 43 \\
\hline (3) Normal saline & 7 & 3 & 4 & 43 & 5 & 2 & 3 & 40 \\
\hline
\end{tabular}

TABLE IV Total area of lesions at days 1, 2, and 7 after commencement of treatment and as a percentage of the pretreatment area at Day 0

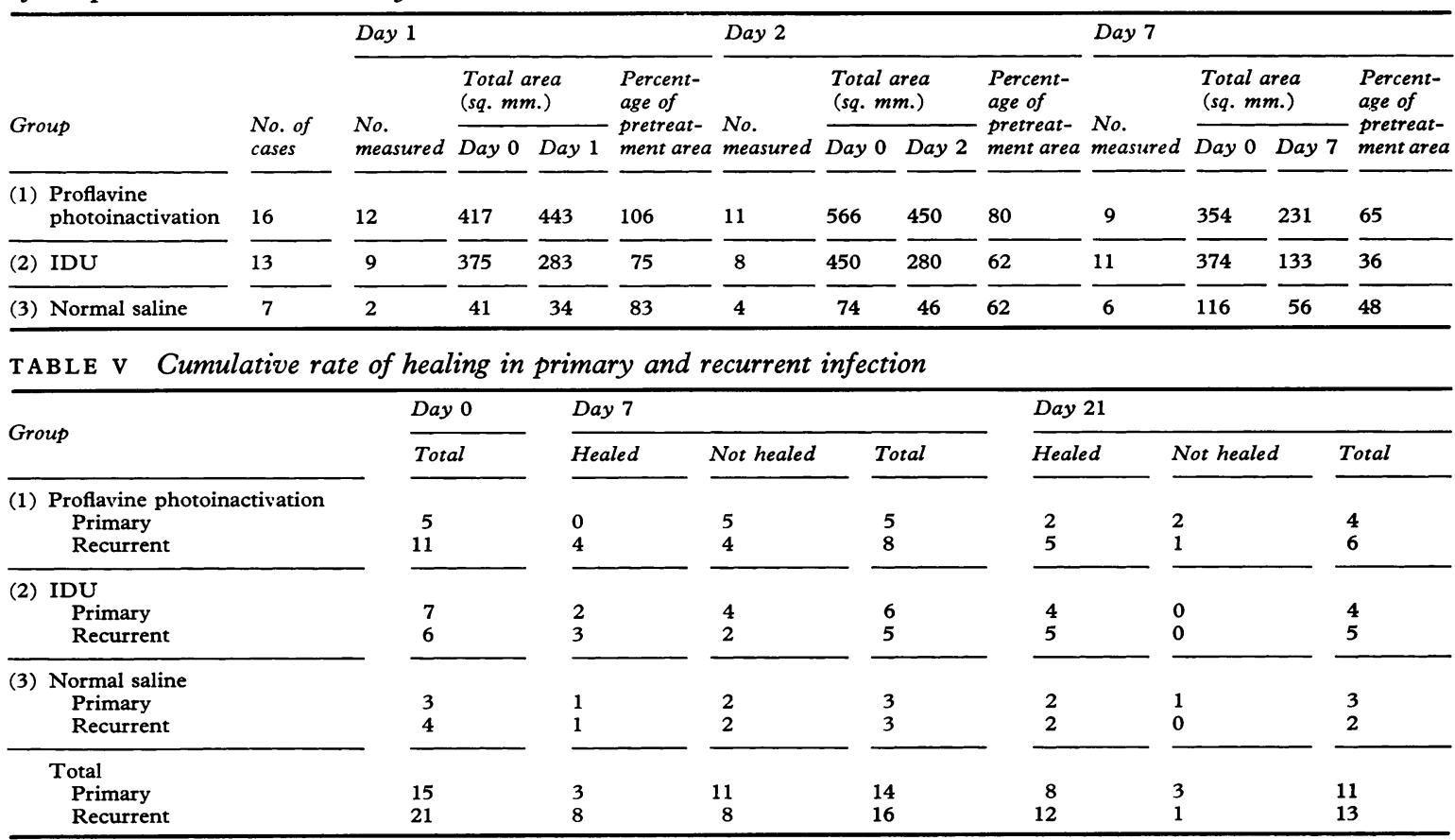


virus as determined by HSV culture was also quicker in the recurrent cases (Table VI).

Symptoms (pain, discomfort, and irritation) were each scored at each visit as 1 (if present) and 0 (if absent). The duration of symptoms after treatment in the three groups is shown in Table VII. No symptoms were present in any group after 7 days.

There was some correlation between the rate of healing of the lesions and the initial size of the lesions (Table VIII). The larger the initial lesion, the longer it took to heal.

\section{Discussion}

By the use of an objective assessment by measurement of the lesions at each attendance, it has been demonstrated that with proflavine photoinactivation the area of the lesions was larger at all stages of treatment when compared with the initial area, than in the groups treated with IDU or normal saline (Table IV). This difference is significant at the level of $P<0.01$ in both groups. In four cases the affected areas became larger (two of them markedly so) after treatment for one day with proflavine, while lesions in only one case in each of the other two groups increased in size after the first day. The healing time was also longer in the proflavine group compared with the other two groups (Table II) and the time of disappearance of the virus as measured by culture for HSV was longer in the proflavine group compared with the other two groups (Table III).

Rawls, Gardner, Flanders, Lowry, Kaufman, and Melnick (1971) stated that recurrent infections by HSV were milder and the virus was more quickly eliminated than in patients with primary infections. This was borne out by our results (Tables V, VI). It was stated in the fournal of the American Medical Association (1971) that lesions on the glans and prepuce healed faster than those on the shaft. In our study there was no correlation between the site of the lesion or the duration of symptoms before treatment and the rate of healing. Only one of the 39 patients with a positive culture for HSV had been circumcised compared with two of the nineteen patients with a negative culture for HSV.

TABLE VI Results of cultures for HSV after treatment-primary and recurrent infections

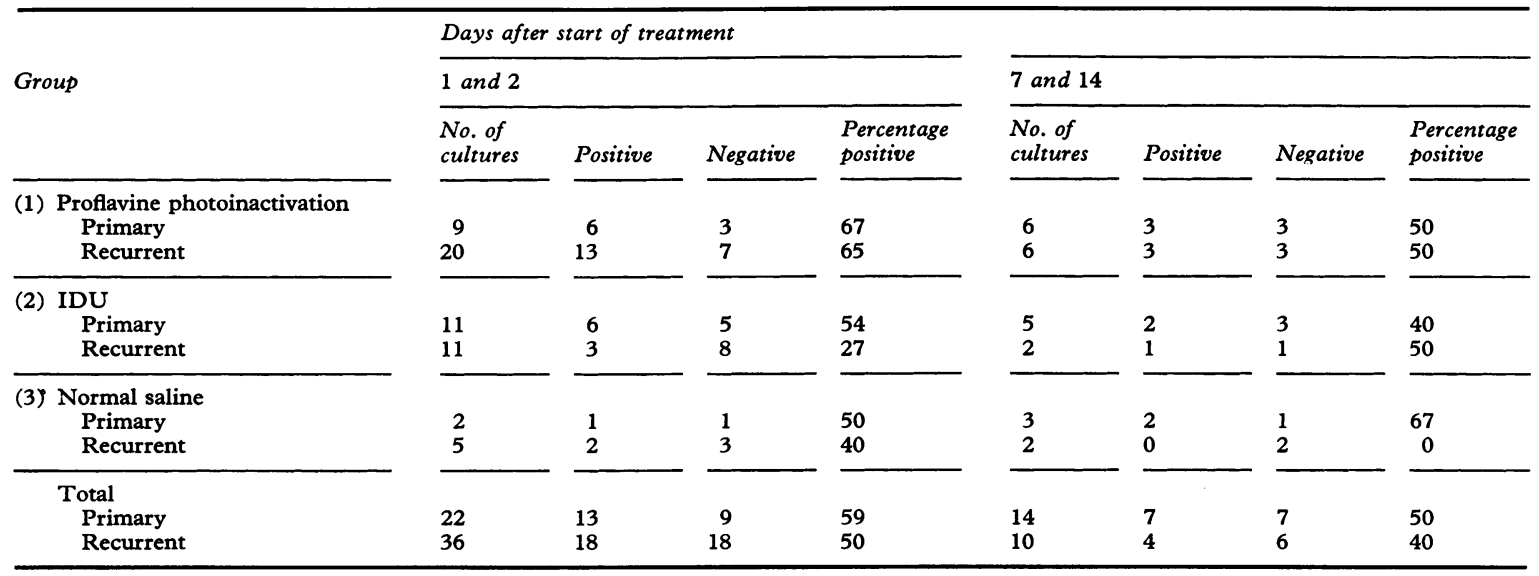

TABLE VII Presence of symptoms (scored as 1 for present, 0 for absent)

\begin{tabular}{|c|c|c|c|c|c|c|c|c|c|}
\hline \multirow{2}{*}{ Group } & \multirow{2}{*}{$\frac{\text { Symptoms }}{\text { Day }}$} & \multicolumn{4}{|c|}{ All (pain, irritation, discomfort) } & \multicolumn{4}{|c|}{ Pain only } \\
\hline & & 0 & 1 & 2 & 7 & 0 & 1 & 2 & 7 \\
\hline (1) Proflavine photoinactivation & Score & 20 & 10 & 6 & 0 & 8 & 3 & 3 & 0 \\
\hline (2) IDU & Score & 13 & 5 & 2 & 0 & 5 & 1 & 1 & 0 \\
\hline (3) Normal saline & Score & 8 & 3 & 1 & 0 & 3 & 1 & 0 & 0 \\
\hline
\end{tabular}

TABLE VII I Size of initial lesion in relation to healing time

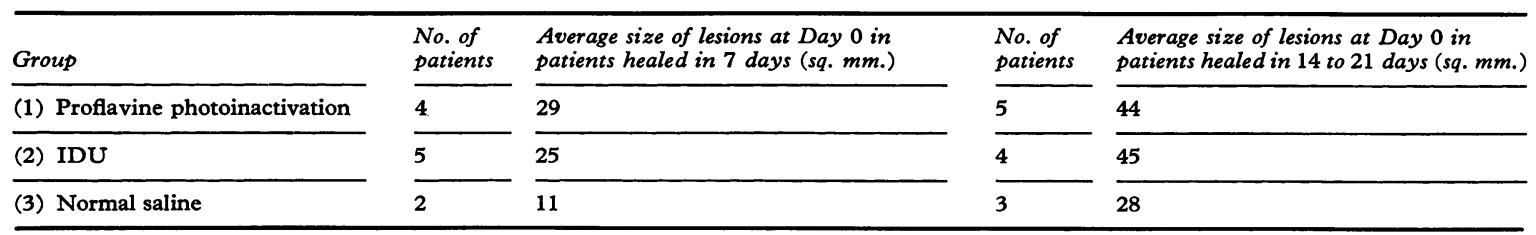


The finding of Kaufman, Gardner, Brown, Wallis, Rawls, and Melnick (1973) that there was no dramatic relief of pain with photoinactivation has been substantiated (Table VII). While Felber and others (1973) described photodynamic inactivation as safe, two acute allergic reactions were described by Lefebvre and McNellis (1973) in areas surrounding those exposed to neutral red, both occurring in patients with a past history of allergy.

We may conclude that proflavine photoinactivation is of no greater value in the treatment of genital infection by HSV in the male than 0.5 per cent. IDU or normal saline. There was no significant difference in the results of treatment by the latter two methods.

\section{Summary}

36 male patients with genital infection by HSV confirmed by culture were each allocated to one of three treatment groups:

(1) Proflavine photoinactivation,

(2) 0.5 per cent. idoxuridine ointment (IDU),

(3) Normal saline.

They were assessed objectively at each attendance by measurement of the lesions with an operating microscope fitted with a measuring grid in one eyepiece. Material for culture for HSV was taken at each visit; the presence of symptoms (pain, discomfort, and irritation) was noted.

The areas of lesions in the proflavine photoinactivation group remained larger significantly longer than in the other groups, the healing time was slower, and HSV could be isolated for longer. It is concluded that proflavine photoinactivation is of no greater value than 0.5 per cent. IDU or normal saline in the treatment of genital infection by HSV in the male.

The authors wish to thank Dr. E. M. C. Dunlop for his advice and help in the preparation of this paper.

\section{References}

Brit. med. F. (1974) 2, 461

Felber, T. D., Smith, E. B., Knox, J. M., Wallis, C., and Melnick, J. L. (1971) Presented at Scientific Assembly of Amer. med. Ass. Section of Dermatology, June 21, 1971

$\longrightarrow,-,-(1973)$ f. Amer. med. Ass., 223, 289

FrIEDRICH, E. G. (1973) Obstet. and Gynec., 41, 74

Hiatt, C. W., Kaufmann, E., Helprin, J. J., and BARON, S. (1960) F. Immunol., 84, 480

HutField, D. C., (1964) Brit. F. vener. Dis., 40, 210

F. Amer. med. Ass. (1971) 217, 270

Juel-Jensen, B. E. (1973) Brit. F. Hosp. Med., 10, 402
Kaufman, H. E., Martola, E. L., and Dohlman, C. H. (1962) Arch. Ophthal. (Chicago), 68, 235

KaUfMaN, R. H., GARDNER, H. L., BROWN, D., Wallis, C., Rawls, W. E., and Melnick, J. L. (1973) Amer. $\mathcal{F}$. Obstet. Gynec., 117, 1144

Lefebvre, E. B., and McNellis, E. E. (1973) f. Amer. med. Ass., 224, 1039

Moore, C., Wallis, C., MelNick, J. L., and Kuns, M. D. (1972) Infect. and Immun., 5, 169

Ng, A. B. P., Reagan, J. W., and Yen, S. S. C. (1970) Obstet. and Gynec., 36, 645

Perdrau, J. R., and Todd, C. (1933) Proc. roy Soc. Lond. (Biol.), 112, 228

Person, D. L., Sheridan, P. J., and Hermann, E. C. (1972) Infect. and Immun., 2, 815

Prusoff, W. H. (1967) Pharmacol. Rev., 19, 209

RAAB, O. (1900) Z. Biol., 39, 524

Rawls, W. E., Gardner, H. L., Flanders, R. W., LOWRY, S. P., KAUfMaN, R. H., and MELNICK, J. L. (1971) Amer. F. Obstet. Gynec., 110, 682

SChNeIDER, G. T., and GeARY, W. L. (1971) Clin. Obstet. Gynec., 14, 1057

Schofield, C. B. S. (1964) Brit. F. Derm., 76, 465

SHORTT, H. E., and BROOKS, A. G. (1934) Indian F. med. Res., 21, 581

STUART, R. D. (1946) Glasg. med. F., 27, 131

Wallis, C., and MeLnick, J. L. (1964) Virology, 23, 520

- - (1966) Photochem. Photobiol., 4, 159

- - - and Kaufman, R. H. (1972) Clin. Obstet. Gynec., 15, 939

Yамамото, N. (1958) f. Bact., 75, 443

Comparaison du traitement de l'herpès génital chez l'homme par la photoinactivation à la proflavine, par la pommade à l'idoxuridine et par le sérum physiologique

\section{SOMMAIRE}

36 hommes atteints d'infection génitale due au virus de l'herpès simplex et dont le diagnostic avait été confirmé par culture, furent répartis dans l'un des trois groupes thérapeutiques suivants:

(1) Photoinactivation à la proflavine;

(2) Pommade à 0,5 pour cent d'idoxuridine (IDU);

(3) Sérum physiologique.

Les résultats furent appréciés objectivement en mesurant les lésions avec un microscope muni d'une grille de mesure dans un oculaire. À chaque visite, un prélèvement fut fait pour la culture du virus et l'existence de symptômes (douleur, inconfort et irritation) furent notés.

La dimension des lésions dans le groupe traité par la photoinactivation à la proflavine se montra plus grande que dans les autres groupes; le temps de guérison fut plus lent et le virus put être retrouvé plus longtemps. On conclut que la photoinactivation à la proflavine n'a pas une valeur plus grande que l'IDU (à 0,5 pour cent) ou le sérum physiologique dans le traitement de l'infection génitale par le virus de l'herpès simplex de l'homme. 